\title{
TINJAUAN YURIDIS TERHADAP HUKUM WARIS ISLAM DI NEGARA JEPANG
}

\author{
Sulhiyah, Khifni Kafa Rufaida \\ hiyaroe@gmail.com, khifnikafarufaida@gmail.com, \\ Dosen Fakultas Hukum Universitas Ngudi Waluyo
}

\begin{abstract}
Abstrak
Ciri khas Negara Jepang terletak pada kebudayaan tradisionlanya yang bertahan sampai saat ini. Dalam kebudayaan tradisional Jepang kita akan melihat salah satu sistem kelompok sosial yang sampai saat ini masih dipertahankan yaitu sistem Ie. Secara garis besar. Berbeda dengan di Indonesia, yakni terdapat tiga sistem pewarisan, karena begitu kentalnya budaya masyarakat Jepang pembagian waris pun dilakukan dengan cara adat. Dimana ketentuan adat tersebut sangat jauh berbeda dengan ketentuan dalam hukum waris Islam (ilmu faraidh). Hal ini menarik, karena beberapa Masyarakat Jepang pun ada yang berkepercayaan Islam. Metode Penelitian yang digunakan adalah analisa deskriptif kualitatif yaitu pengolahan data yang didasarkan pada hasil studi lapangan yang kemudian dipadukan dengan data yang diperoleh dari Studi Kepustakaan, sehingga dari sana akan diperoleh data yang akurat sedangkan permasalahannya dilakukan dengan menggunakan pendekatan yuridis sosiologis. Jika dipandang dari segi Islam, kebiasaan nakayoushi yang ada di Jepang tidak mencerminkan keadilan yang sesuai dengan syari'at Islam. Padahal sebagaimana yang kita ketahui, hukum waris dibentuk sedemikian rupa dan diwujudkan dalam suatu ilmu waris Islam atau biasa disebut ilmu faraidh adalah semata-mata untuk menghindari dari permusuhan dan menciptakan suatu keadilan bagi umat muslim di dunia.
\end{abstract}

Kata Kunci: Hukum Waris Islam, Waris Jepang

\section{A. PENDAHULUAN}

Jepang adalah salah satu negara dengan pengaruh budaya yang kuat, dilihat dari tinjauan sejarah peradaban Jepang yang cukup kompleks. Budaya Jepang menjadi salah satu jalan Jepang berkembang sebagai satu dari sekian negara maju di dunia. Karena kedisiplinan dan tertibnya masyarakat Jepang itulah yang menjadi dasar Jepang menjadi Negara maju yang selalu dijadikan Role model atau panutan dalam hal pendidikan. Bagaimana kedispilinan dan ketertiban ini 
terbentuk dalam masyarakat Jepang, karena hal ini lahir dari budaya khas yang dimiliki oleh Negara Jepang.

Ciri khas kebudayaan Negara Jepang terletak pada kebudayaan tradisionlanya yang bertahan sampai saat ini. Dalam kebudayaan tradisional Jepang kita akan melihat salah satu sistem kelompok sosial yang sampai saat ini masih dipertahankan yaitu sistem Ie. Jika diterjemahkan dalam bahasa Indonesia adalah keluarga. Akan tetapi pada kenyataannya, makna dari ie lebih dari itu. Ie adalah tempat dimana anggota keluarga berkumpul dan atau tempat mereka melaksanakan kehidupan sosial bersama-sama, maka dalam kehidupan sosial masyarakat Jepang tidak ada ikatan kelompok individual satu terhadap yang lain, tetapi juga ikatan yang setiap individu satu dengan individu yang lain. Secara garis besar bahwa fungsi ie adalah untuk melestarikan peralatan atau harta $i e$, dan makam. Dalam kepercayaan tradisional Jepang, jika orang tua dalam keluarga sudah meninggal, maka dibuatlah makam keluarga dan juga dibuatlah altar pemujaan di rumah. Kemudian disediakan sesajen atau persembahanpersembahan agar roh orang tua mereka tidak gentayangan.

Dalam garis keturunan yang dianut oleh masyarakat Jepang adalah dari garis keturunan ayah. Sehingga anak laki-laki pertama yang menjadi penerus dalam sistem waris harta maupun keturunan. Maka anak tersebut akan menjadi penerus marga ayah atau keturunan ayah, atau disebut patrilinear. Berbeda dengan di Indonesia, yakni terdapat tiga sistem pewarisan, yang pertama yaitu hukum waris yang terdapat dalam Kitab Undang-Undang Hukum Perdata, buku I Bab XII sampai dengan XVII dari pasal 830 sampai pasal 1130, kedua yaitu hukum waris yang terdapat dalam hukum adat, yaitu dalam bagian hukum waris adat, dan yang ketiga adalah hukum waris yang terdapat dalam hukum waris Islam, yaitu ketentuan dalam hukum waris Islam yang disebut Mawaris atau Ilmu Faraidl, hal ini menarik untuk dibahas untuk melihat bagaimana sistem waris di Jepang dan sistem waris di Indonesia. Melihat begitu kentalnya budaya masyarakat Jepang yang notabebe sebagian masyarakatnya berkepercayaan Islam, maka dibuatlah suatu rumusan permasalahan sebagai berikut: bagaimana pelaksanaan hukum waris Islam di Negara Sakura ini. Dari latar belakang di atas, maka Penulis 
tertarik untuk memberikan suatu kontribusi tentang tinjauan yuridis terhadap hukum waris Islam di Negara Jepang.

\section{B. METODE PENELITIAN}

Metode Penelitian yang digunakan adalah analisa deskriptif kualitatif yaitu pengolahan data yang didasarkan pada hasil studi lapangan yang kemudian dipadukan dengan data yang diperoleh dari Studi Kepustakaan, sehingga dari sana akan diperoleh data yang akurat sedangkan permasalahannya dilakukan dengan menggunakan pendekatan yuridis sosiologis. Yang dimaksud dengan penelitian yuridis sosiologis adalah Penelitian yang digunakan dalam menyelesaikan masalah yang akan dibahas didasarkan pada ketentuan yang berlaku yakni ketentuan dalam Al-Qur'an dan Al-Hadist untuk kemudian dihubungkan dengan kenyataan yang ada dalam masyarakat. Untuk kelengkapan data penulisan maka diperlukan data primer yang diperoleh melalui wawancara yang tidak terarah. Wawancara dilakukan terhadap responden warga negara Jepang yang beragama Islam.

\section{HASIL PENELITIAN DAN PEMBAHASAN}

\section{a. Konsep Ie di Jepang}

Salah satu hal yang menarik dari budaya Jepang adalah sistem keluarga yang dikenal dengan sistem Ie. Sistem ini telah ada sejak zaman feodal, yaitu tepatnya Zaman Edo (1600-1868). Akan tetapi, di zaman itu sistem Ie hanya diberlakukan bagi kalangan bangsawan dan samurai.Sistem Ie merupakan sistem yang mengatur aturan kehidupan keluarga di Jepang. Secara harfiah, Ie berarti keluarga, tetapi konsep keluarga di sini tidak hanya sebatas hubungan darah saja. Kerabat dekat bahkan seorang pengikut (pembantu) yang setia dan telah lama mengabdi di keluarga dapat termasuk ke dalam sistem Ie.

Terdapat dua faktor yang melahirkan sistem $I e$, yaitu kesatuan keluarga yang bersifat patrilinieal dan kesatuan shinzoku yang berpusat pada suami dan istri. Shinzoku adalah hubungan kekerabatan yang terjadi dalam masyarakat Jepang antara ego dengan kerabat lainnya, baik bersifat ketsuzoku yaitu hubungan 
darah yang sama dan hubungan inzoku yaitu hubungan darah yang terjadi antara ego dengan kerabat pasangannya.

Menurut Satoshi Sakata, sistem Ie adalah kerangka sosial yang dirancang untuk meneruskan generasi ke generasi, di mana sebuah tempat tinggal keluarga, nama keluarga, dan bisnis keluarga diwariskan dari ayah ke anak tertua sepanjang garis paternal yang dapat meluas untuk generasi selanjutnya.Anak tertua (lakilaki) akan menjadi pemimpin keluarga yang dikenal dengan sebutan kachou. Dengan begitu, segala warisan akan jatuh ke tangannya termasuk sistem kepemimpinan yang akan diteruskan.

Pada era Restorasi Meiji, pemerintah Meiji mengeluarkan hukum perdata yang dikenal dengan Meiji Minpou atau Undang-Undang Sipil Meiji, pada 1896. Dalam hukum ini, sistem Ieyang sebelumnya hanya berlaku untuk kalangan bangsawan dan samurai, mulai diberlakukan untuk seluruh lapisan masyarakat.Hal ini tak lain merupakan upaya untuk mengejar ketertinggalan dengan dunia Barat, serta, sitem keluarga ini merupakan ideologi politik di masa pemerintahan Meiji.Setelah diberlakukannya, sistem Ie semakin menjadi nilainilai yang mengatur kehidupan. Salah satu yang mengikat adalah struktur chokkei kazoku, yang menjadi struktur dominan di era Meiji. Struktur chokkei kazokuyaitu keluarga tiga generasi tinggal di bawah satu atap menjadikan nilai Iebersifat family oriented.

Di masa ini, keturunan adalah hal yang sangat dinanti, tujuannya untuk meneruskan keluarga. Karena itulah pada masa ini pernikahan meningkat. Menikah, seperti di Zaman Edo, dinilai sebagai harapan terbesar kaum wanita. Sesuai dengan era Meiji yang berorientasi kepada kemajuan bangsa Jepang, pernikahan dan keturunan (terutama laki-laki) dianggap sebagai suatu keharusan untuk nama baik keluarga dan Jepang. Tetapi, pasca Perang Dunia II, terutama dengan fenomena perkembangan ekonomi yang meningkat drastis di Jepang, beberapa nilai-nilai dalam sistem Ie ini cenderung berubah. Perubahan tersebut bahkan mengarah kepada hal yang krusial, terkait dengan masa depan bangsa Jepang itu sendiri. Perubahan yang signifikan terjadi semenjak penghapusan Meiji Minpousecara hukum pada 1947. 
Dalam tradisi masyarakat Negara Jepang hubungan sosial tidak hanya dilatar belakangi oleh nilai-nilai yang memperhitungkan untung dan rugi, melainkan diikat oleh shinzoku teki atau ikatan kekerabatan semu alam kehidupan berkelompok, Situmorang Hamzon, 1996:22 hubungan ini tidak harus berdasarkan ikatan darah, tetapi lebih didasarkan pada kebersamaan menanggung kehidupan sehari-hari. Salah satu kelompok sosial yang mendasar dalam sistem keluarga yang ada di dalam masyarakat tradisional Jepang.

Masyarakat Jepang pada masa pemerintahan Meiji (1868-1912) merasa perlu mengukuhkan sistem kekeluargaan yang mereka jalankan dalam undangundang dasar negaranya yang disebut dengan Meiji Minpo. Pada undang-undang dasar negara disebutkan bahwa sistem kekeluargaan yang dianut oleh masyarakat Jepang adalah sistem ie yang berdasarkan sistem patriakat. Sistem ie ini disebut sebagai sistem kekeluargaan tradisional Jepang yaitu dalam satu keluarga yang dipimpin oleh kepala keluarga yang mengayomi anggota keluarga dalam jumlah cukup besar.

Sugimoto (1997) membuat empat kategori keluarga Jepang yaitu pertama tipe keluarga yang masih kuat menjalankan sistem kekeluargaan tradisional, kedua, tipe keluarga yang struktur anggotanya seperti keluarga besar karena terdiri dari beberapa generasi, namun dalam menjalankan kehidupan sehari-hari mereka terpisah seperti keluarga batih. Ketiga, tipe keluarga batih namun mereka masih meyakini adanya hubungan garis keturunan sehingga walaupun mereka berada jauh dari keluarga asalnya karena alasan pekerjaan dan lain-lain, mereka masih menyempatkan diri untuk hadir pada acara tradisional yang diselenggarakan keluarga besarnya seperti pesta pernikahan tradisional, acara pemakaman, festival daerah, pemujaan arwah leluhur dan lain sebagainya. Keempat, tipe keluarga batih modern yang menjalankan ideologi keluarga modern. Sementara itu, tujuan dari keluarga dalam sistem ie adalah menjaga kesinambungan ie-nya secara turuntemurun. Untuk melaksanakan tujuan dari ie maka di dalam ie ditunjuk seorang kepala keluarga yang disebut dengan kachou. Tugas kachou cukup berat karena kachou bertanggung jawab akan kesejahteraan anggota dan kesinambungan ienya. Dalam menjalankan tugas sebagai pemimpin keluarga sekaligus usaha atau 
bisnis keluarga, kachou dibantu oleh istrinya yang disebut dengan shufu "ibu rumah tangga”. Penentuan siapa yang akan menjadi kachou pada ie biasanya ditentukan berdasarkan garis keturunan dan hubungan darah. Anak laki-laki tertua/pertama dari kachou yang disebut dengan chounan biasanya disiapkan untuk menjadi pewaris bila kachou pensiun atau meninggal dunia.

Satjipto Rahardjo, penggagas Hukum Progresif di Indonesia, beberapa kali membandingkan hukum Indonesia dan hukum Jepang di beberapa bukunya. Berangkat dari pemikiran sederhana bahwa Indonesia dan Jepang memiliki kesamaan dalam hal 'pencangkokan' hukum. Keduanya memiliki budaya hukumnya sendiri hingga kemudian budaya hukum modern diperkenalkan dan 'dicangkokan' (transplanted) kepada Indonesia dan Jepang. Jepang memiliki resistensi yang lebih kuat dibanding Indonesia terhadap hukum modern. Budaya hukum Jepang masih terasa meskipun menggunakan hukum modern. Indonesia mengenal hukum modern melalui penjajahan yang dilakukan Belanda, negara yang sedang dijajah Perancis saat menjajah kita.

Jepang menjadi negara sekuler, memisah tegas ranah agama dan negara. Dalam pandangan agama Shinto, kaisar adalah perwakilan Tuhan, sehingga jika kaisar menginginkan perang maka rakyat harus patuh, dan keinginan kaisar ini yang dipercaya Amerika memicu Jepang untuk berkuasa dan menyerang beberapa negara lain (termasuk Indonesia). Maka agama harus dipisah tegas dari negara. Ini menjadi latar belakang mengapa negara ini kemudian menjadi negara sekuler. Sehingga itu pula sebabnya hingga kini agama tidak diajarkan di sekolah-sekolah negeri di Jepang. Sebelumnya leluhur Jepang banyak menganut Shinto dan Buddha, saat ini sebagian besar orang Jepang tidak begitu percaya pada agama kecuali hanya sebatas budaya.

Seiring berkembangnya jaman banyaknya Negara asing yang masuk ke Jepang baik untuk bekerja mau pun sebagai pelajar di Jepang, maka semakin banyak pula agama yang masuk ke dalam Negara Jepang, salah satunya yaitu Islam, dan bahkan melihat kondisi sekarang Islam benar-benar akan meliputi ujung timur dan barat dunia, termasuk ke negeri Jepang.Sekalipun jumlah Muslim di Jepang masih kecil, namun berkembang pesat. Diperkirakan jumlah muslim di 
jepang sekitar 110.000 hingga 120.000, termasuk sekitar 10.000 Muslim asli Jepang.

Dalam konteks sistem hukum, hukum dibagi kedalam tiga subsistem: substansi hukum, struktur hukum dan budaya hukum. Substansi hukum berkaitan denganrule of law, aturan materil dan formil dari suatu hukum. Struktur hukum adalah instrumen struktur penegakan hukum seperti advokat, kepolisian, kejaksaan, pengadilan dan lembaga pemasyarakatan. Budaya hukum adalah nilainilai dan harapan-harapan terhadap hukum.

Tetapi untuk hukum waris yang digunakan masih menggunakan hukum jepang yang berlaku, hukum yang digunakan adalah wasiat atau amanat yang telah ditulis oleh orang tua mereka atau orang yang berkuasa di dalam keluarga mereka. Atau jika mereka dari kalangan ekonomi atas maka biasanya wasiat yang ditulis dipegang oleh pengacara atau kuasa hukum yang mereka percayai. Pembagian waris di jepang adalah anak laki-laki pertama yang akan menjadi penguasa harta pusaka yang tidak terpecah belah, bahkan bertambah secara kumulatif. Mereka tetap tinggal di desa menjadi warga inti yang memiliki rasa tanggung jawab maksimal terhadap tanah pusaka dan yang memiliki loyalitas yang besar terhadap komunitasnya.

Karena mobilitasnya yang minimal jumlah penduduk desa stabil sepanjang masa, kenaikan penduduk Jepang berlangsung lambat dan baru melonjak setelah perang dunia ke dua, kemudian turun lagi kira-kira sejak sepuluh tahun terakhir. Sebaliknya penyerapan semakin lama semakin bertambah. Sekarang jumlah orang jepang yang bekerja dalam lapangan pertanian dikabarkan naik $15 \%$ setiap tahunnya.Berbeda dengan Indonesia karena sudah memiliki hukum sesuai dengan hukum Negara atau pun hukum waris Islam. Tanah warisan sudah terbagi-bagi berdasarkan hukum yang berlaku atau hukum bilateral.

\section{b. Hukum Kewarisan Islam}

Persoalan waris merupakan hal yang penting dan diperhatikan oleh agama Islam. Tujuan pengaturan mengenai harta waris ini dimaksudkan agar tidak ada sengketa yang muncul di kemudian hari. Menurut Hasby As-Shiddiqi, fiqih 
mawaris adalah ilmu yang dengan dia dapat diketahui orang-orang yang mewarisi, orang-orang yang tidak dapat mewarisi, kadar yang diterima oleh masing-masing ahli waris serta cara pengambilannya. Hukum waris Islam biasa disebut juga dengan Ilmu Faraidh. Seorang ilmuan fiqh, Ibnu Rusyd mendefinisikan ilmu faraidh sebagai ilmu yang digunakan untuk mengetahui cara membagi harta peninggalan seseorang yang telah meninggal dunia kepada yang berhak menerimanya. Dalam hukum kewarisan Islam kita mengenal beberapa asas:

1) Asas Ijbari

2) Asas Bilateral

3) Asas Individual

4) Asas Keadilan Berimbang

5) Asas Semata Akibat Kematian

Menurut Sayid Sabiq, seseorang dapat mewarisi harta warisan karena 3 (tiga) hal yaitu: adanya hubungan kekerabatan, adanya perkawinan, dan perbudakan. Selain itu ada beberapa hal yang menyebabkan seseorang tidak dapat mewaris antara lain tindakan atau hal-hal yang dapat menggugurkan hak seseorang untuk mewaris seperti membunuh Pewaris dan Murtad.

Dalam ilmu faraidh dikenal istilah Ashabul furudh yaitu para ahli waris yang bagian yang sudah ditentukan dalam ayat Al-Qur'an, beberapa bagian yang telah ditentukan yaitu $2 / 3,1 / 2,1 / 3,1 / 4,1 / 6$ dan 1/8. Yang dimaksud ahli waris adalah mereka yang jelas-jelas mempunyai hak waris ketika pewarisnya meninggal dunia. Ahli waris adalah orang yang berhak mendapatkan warisan (ashabul furudh) dari kaum laki-laki ada 15 (lima belas) yaitu: anak laki-laki, cucu laki-laki (dari anak laki-laki), bapak, kakek (dari pihak bapak), saudara kandung laki-laki, saudara laki-laki seayah,saudara laki-laki seibu, anak laki-laki dari saudara kandung laki-laki, anak laki-laki dari saudara kandung laki-laki seibu, paman (saudara kandung bapak), paman (saudara kandung ayah), anak lakilaki dari paman (saudara kandung ayah), anak laki-laki paman seayah, suami, dan laki-laki yang memerdekakan budak. Adapun ahli waris (ashabul furudh) dari kaum wanita ada 10 (sepuluh) yaitu: anak perempuan, ibu, anak perempuan (dari keturunan anak laki-laki), nenek (ibu dari ibu), nenek (ibu dari bapak), saudara 
kandung perempuan, saudara perempuan seayah, saudara perempuan seibu, istri dan perempuan yang memerdekakan budak.

Jika seluruh ashabul furudh yang berjumlah 25 orang itu ada semua maka yang berhak mendapatkan harta warisan adalah ayah, ibu, anak laki-laki, anak perempuan, suami/isteri. Adapun furudul muqaddarah yang ditetapkan oleh hukum waris bersifat pasti dan wajib dilaksanakan berdasarkan asas hukum waris Islam yaitu asas ijbari.

\section{c. Tinjauan Yuridis terhadap Hukum Waris Islam di Negara Jepang}

Dalam hukum waris purwa Islam dikenal dua bentuk sistem kewarisan yaitu hukum kewarisan testamentair dan hukum kewarisan abintestato. Kewarisan testamentair dapat diinterpretasi dari Q.S. An-Nisa. Ada sebuah hadist yang diriwayatkan Sa'ad bin Abi Waqqas:

"Sa'ad bin Waqas bercerita bahwa sewaktu ia sakit parah dan Rasulullah SAW mengunjunginya, ia bertanya kepada Rasulullah: "Saya mempunyai harta yang banyak, sedangkan saya hanya mempunyai seorang anak perempuan yang akan mewarisi saya. Saya sedekahkankah dua per tiga dari harta saya? Rasulullah menjawab: Jangan! Maka bertanya lagi Sa'ad: Bagaimana jika seperdua? Rasulullah menjawab lagi: Jangan! Setelah itu bertanyalah lagi Sa'ad: Bagaimana jika sepertiga? Maka berkata Rasulullah: besar jumlah sepertiga itu sesungguhnya jika engkau tinggalkan anamku dalam berkecukupan adalah lebih baik.” (HR. Bukhori).

Sebagaimana yang dijelaskan dalam bab sebelumnya bahwa hukum waris yang digunakan pada masyarakat Jepang adalah wasiat atau amanat yang telah ditulis orang taunya. Artinya di Negara Sakura ini menyamakan wasiat dengan warisan. Menurut kebiasaan di sana pembagian waris di jepang adalah anak lakilaki pertama yang akan menjadi penguasa harta pusaka yang tidak terpecah belah, bahkan bertambah secara kumulatif. Lalu bagaimana dengan Warga Negara Jepang yang notabene beragama Islam. Padahal kita tahu, bahwa islam mengatur sedemikian pembagian waris Islam ke dalam suatu bidang ilmu yaitu ilmu faraidh. 
Hukum Islam sendiri mengenal adanya hukum waris dan wasiat. Keduanya merupakan sesuatu yang wajib untuk dilaksanakan dengan sungguh-sungguh, karena masing-masing memiliki dasar hukum baik dari Al-Qur'an, Sunnah maupun Ijma' ulama. Dalam pelaksanaan keduanya, Islam mengatur pembagiannya pada masing-masing wilayah sendiri-sendiri. Kapan saatnya menggunakan wasiat dan kapan pula menggunakan hukum waris sudah diatur sedemikian rupa. Sehingga keduanya tidak mungkin tumpang tindih jika kita melaksanakan syari' at ini dengan benar.

Sebenarnya antaa wasiat dan waris Islam, wasiat lebih dahulu diturunkan. Wasiat pun telah diatur dalam Q.S. Al-Baqarah: 180 yang berbunyi: "Diwajibkan atas kamu, apabila seorang di antara kamu kedatangan maut, jika ia meninggalkan harta yang banyak, berwasiat untuk ibu-bapak dan karib kerabatnya secara ma'ruf. Hal itu adalah kewajiban atas orang-orang yang bertaqwa."

Pada saat ayat ini turun, belaku hukum kewajiban untuk menjalankan wasiat dan siapa yang melanggar wasiat almarhum, tentu dia akan berdosa besar. Namun demikian, syari'at Islam itu turun secara berangsur-angsur. Ada beberapa hukum yang sejak awal ditetapkan sedemikian rupa, namun pada masa tasyri' (proses pensyari'atan) Allah SWT berkehendak mengubah dengan hukum yang turun kemudian. Dalam ilmu ushul fiqih dikenal dengan istilah nasakh dan mansukh.

Hukum waris merupakan hukum yang turun kemudian setelah sebelumnya Sang Khalik memberlakukan hukum wasiat. Dengan adanta ketentuan hukum waris dalam Islam, sebagian dari hukum wasiat menjadi tidak berlaku lagi. Untuk itu, apabila ada ketentuan wasiat yang bertentang dengan ketentuan waris, maka ketentuan wasiat harus diabaikan. Sebaliknya jika ketentuan wasiat tidak bertentangan dengan hukum waris maka wasiat wajib untuk tetap dijalankan.

Turunnya ayat yang menerangkan tentang waris ini kemudian menetapkan bahwa ahli waris tidak diperbolehkan (haram) menerima harta warisan melalui jalur wasiat. Seluruh umat muslim sudah seharusnya tunduk dan patuh kepada ketentuan Allah SWT ini. Sebagaimana dalam hadist Nabi Muhammad SAW: "Sesungguhnya Allah telah memberikan setiap orang masing-masing haknya. Maka tidak boleh harta itu diwasiatkan kepada ahli waris (H.R. At-Tirmidzi). 
Apabila melihat ketentuan dalam hadist Tirmidzi ini maka dapat disimpulkan bahwa seorang Pewaris sudah tidak lagi diperbolehkan untuk membuat wasiat, apabila penerima wasiat adalah ahli warisnya yang termasuk dalam ashabul furudh. Apabila seorang Pewasiat ingin membuat wasiat maka ia harus berwasiat hanya kepada selain ahli waris. Selanjutnya mengenai bagian maksimal yang dapat diwasiatkan hanyalah $1 / 3$ (sepertiga) bagian saja, sedangkan sisanya $2 / 3$ bagian adalah mutlak bagian ahli waris. Sebagaimana Sabda Rasulullah SAW kepada Saad bin abi Waqqash di atas.

Namun demikian, hukum waris Islam ini banyak dilanggar oleh muslim dan muslimah di Jepang. Mereka lebih cenderung menggunakan hukum waris sesuai dengan adat kebiasaan disana, dimana wasiat disamakan dengan warisan. Maka harta waris yang mereka terima berupa harta yang tertulis di sebuah kertas peninggalan orang tua yang ditujukan pada anak mereka yang tercantum dalam surat wasiat tersebut, jika salah satu anak dari keturunan mereka tidak tercantum dalam surat tersebut walau masih ada hubungan darah sebagai anak kandung, maka mereka tidak berhak untuk mendapatkan harta waris walau satu rupiah pun. Biasanya yang paling banyak mendapatkan harta waris adalah mereka yang memiliki nakayoushi (hubungan keakraban) dengan orang tua paling dekat walau bukan anak pertama di dalam keluarga. Tetapi jika di dalam keluarga memiliki orang tua yang adil maka semua anak dalam keluarga mendapatkan warisan walau banyak sedikitnya mungkin berbeda satu dengan yang lain.

Di Negara Jepang dikenail istilah ie yang memiliki arti untuk melestarikan peralatan atau harta ie, dan makam. Dalam garis keturunan yang dianut oleh masyarakat Jepang adalah dari garis keturunan ayah. Sehingga anak laki-laki pertama yang menjadi penerus dalam sistem waris harta maupun keturunan. Maka anak tersebut akan menjadi penerus marga ayah atau keturunan ayah, atau disebut patrilinear. Sebetulnya pada hukum waris Islam pun menyiratkan hal ini dalam Q.S. An-Nisa dimana bagian laki-laki dengan perempuan perbandingannya adalah 2:1.

Jika ditinjau secara yuridis, seharusnya seseorang yang beragama Islam dimana pun ia berada, di negara manapun ia menundukkan diri, ia harus tetap 
melaksanakan syari'at Islam secara benar. Tidak terkecuali masyarakat muslim yang berada di Negara Jepang. Kedudukan wasiat dalam hukum waris Islam memang hal yang penting. Hal ini terbukti dengan adanya ayat-ayat Al-Qur'an yang menerangkat mengenai wasiat baik pada saat sebelum turunnya ayat kewarisan mapun saat setelah turunnya ayat kewarisan. Tuntunan kewarisan ini sebagaimana firman Allah dalam beberapa Surat dalam Al-Qur'an antara lain Q.S. Al-Baqarah: 180-182, dan 240, QS. An-Nisa': 11 dan 12 serta Q.S. Al-Ahzab: 6. Berikut salah satu ayat dalam QS. Al-Baqarah ayat 180 yang berbunyi:

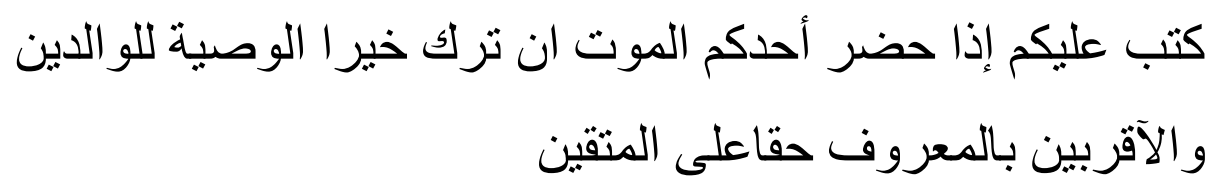

"Diwajibkan atas kamu, apabila maut hendak menjemput seseorang di antara kamu, jika ia meninggalkan harta, berwasiat untuk kedua orang tua dan karib kerabat dengan cara yang baik, (sebagai) kewajiban bagi orang-orang yang bertaqwa".

Selain kita mengenal ilmu fiqih, kita mengenal pula ilmu ushul fiqh yang mana ada bagian yang sangar erat dengan pembicaraan ayat-ayat Al-Qur'an tersebut. Ajaran yang dimaksud adalah ajaran untuk menjawab pertanyaan apakah ayat yang satu dapat menghapus (me-mansukh-kan) ayat yang terdahulu, yang membicarakan hal yang sama. Ada beberapa yang mengatakan mansukh (hapus kekuatannya) dan ada pula yang mengatakan tidak. Sebagai contoh, adanya Firman Q.S. Al-Baqarah: 180 yang turun lebih dahulu pada urutan ke-87 dari ayat An-Nisa' yang turun pada urutan ke-92.

Pada Kewarisan Bilateral berkesimpulan bahwa memberi wasiat sebagaimana dalam Surat Al-Baqarah tersebut dapat dilakukan Pewaris kepada Siapa saja dan badan apa saja asalkan dalam rangka kebaikan, misalnya untuk memperbaiki masjid. Bahkan menurut ajaran ini, berwasiat pada Ahli Waris yang ikut mewaris tidak dilarang. Menurut pendapat ini, hubungan garis hukum mengenai wasiat dalam Surat Al-Baqarah 180 dengan garis hukum wasiat dalam 
Surat An-Nisa' ayat 11 dan 12 tidak menghapus berlakunya seluruh ketentuan ayat 180. Namun hukumnya yang berubah, hukum yang sebelumnya diwajibkan (kutiba') beralih menjadi ringan berupa kebolehan (ibahah).

Pendapat ajaran lain yakni kewarisan patrilineal (Imam Syafi'i) mengatakan bahwa dengan turunnya ayat Q.S. An-Nisa: 7, 11, 12 dan 176, maka Surat AlBaqarah tersebut menjadi tidak berlaku lagi. Dengan kata lain, tidak diperbolehkan untuk berwasiat kepada bapak dan aqrabun, bahkan tidak diperbolehkan berwasiat kepada ibu, bapak, dan aqrabun, apabila ketiganya tersebut sudah mendapat bagian warisan dalam suatu kewarisan. Selanjutnya dalam Al-Hadist dijelaskan bahwa tidak ada wasiat bagi ahli waris. Menurut ajaran ini, kekuatan Q.S. Al-Baqarah ayat 180 telah dihapus (mansukh). Dengan demikian disimpulan oleh ajaran ini bahwa berwasiat di sini hanya untuk kemaslahatan umum.

Para ahli hukum Islam sepakat bahwa batas maksimal harta warisan yang boleh diwasiatkan adalah 1/3 (sepertiga) bagian. Dasar ketentuannya adalah Hadis Sa'ad bin Abi Waqas sebagaimana yang telah disebutkan pada sub bab sebelumnya. Apabila ada wasiat Pewaris yang melebihi batas maksimal tersebut maka dapat diselesaikan dengan:

1) dikurangi sampai batas maksimal yaitu satu per tiga bagian;

2) diminta kesediaan semua ahli waris yang pada saat itu berhak menerima waris, apakah mereka mengikhlaskan kelebihan wasiat atas sepertiga bagian harta warisan itu atau tidak. Apabila mengikhlaskan, maka halal dan ibahah hukumnya begitupun sebaliknya jika tidak ada keihlasan, maka wasiat hanya boleh dilaksanakan sesuai dengan batas maksimal.

Kebiasaan adat yang dipakai oleh masyarakat muslim di Negara Jepang jelas tidak sesuai dengan ketentuan dalam hukum Islam. Untuk itulah, seharusnya warga muslim di sana mengedepankan prinsip Al-Qur'an dan Al-Hadist daripada adat istiadat yang ada di sana. Jika dipandang dari segi Islam, kebiasaan nakayoushi yang ada di Jepang tidak mencerminkan keadilan yang sesuai dengan syari'at Islam. Padahal sebagaimana yang kita ketahui, hukum waris dibentuk sedemikian rupa dan diwujudkan dalam suatu ilmu waris Islam atau biasa disebut 
ilmu faraidh adalah semata-mata untuk menghindari dari permusuhan dan menciptakan suatu keadilan bagi umat muslim di dunia.

\section{PENUTUP}

Masyarakat Jepang pada masa pemerintahan Meiji (1868-1912) merasa perlu mengukuhkan sistem kekeluargaan yang mereka jalankan dalam undangundang dasar negaranya yang disebut dengan Meiji Minpo. Untuk melaksanakan tujuan dari ie maka di dalam ie ditunjuk seorang kepala keluarga yang disebut dengan kachou yang bertugas bertanggung jawab akan kesejahteraan anggota dan kesinambungan ie-nya. Jepang menjadi negara sekuler, memisah tegas ranah agama dan negara. Dalam pandangan agama Shinto, kaisar adalah perwakilan Tuhan, Seiring berkembangnya jaman banyaknya Negara asing yang masuk ke Jepang baik untuk bekerja mau pun sebagai pelajar di Jepang, maka semakin banyak pula agama yang masuk ke dalam Negara Jepang, salah satunya yaitu Islam. Hukum waris yang digunakan masih menggunakan hukum jepang yang berlaku, hukum yang digunakan adalah wasiat atau amanat yang telah ditulis oleh orang tua mereka atau orang yang berkuasa di dalam keluarga mereka.

Sebenarnya antara wasiat dan waris Islam, wasiat lebih dahulu diturunkan. Wasiat pun telah diatur dalam Q.S. Al-Baqarah: 180 yang berbunyi: "Diwajibkan atas kamu, apabila seorang di antara kamu kedatangan maut, jika ia meninggalkan harta yang banyak, berwasiat untuk ibu-bapak dan karib kerabatnya secara ma'ruf. Hal itu adalah kewajiban atas orang-orang yang bertaqwa." Turunnya ayat yang menerangkan tentang waris ini kemudian menetapkan bahwa ahli waris tidak diperbolehkan (haram) menerima harta warisan melalui jalur wasiat. Selain itu, para ahli hukum Islam sepakat bahwa batas maksimal harta warisan yang boleh diwasiatkan adalah 1/3 (sepertiga) bagian. Tentunya kebiasaan adat ini tidak sesuai dengan ketentuan dalam hukum Islam. Untuk itulah, seharusnya warga muslim di sana mengedepankan prinsip Al-Qur'an dan Al-Hadist daripada adat istiadat yang ada di sana. 


\section{DAFTAR PUSTAKA}

Al-Qur'an.

Al-Hadist.

Anne E Imamura, The Japanese Family, 1990, dikutipdarihttp://www.exeas.org/resources/pdf/japanese-familyimamura.pdf, diakses 4 Februari 2014 NN, dikutipdari http://repository.usu.ac.id/bitstream/123456789/37838/3/Chapter\%20II.p df, diakses 5 Februari 2014

Emiko, Ochiai, 1994, The Japanese Family System in Transition: A Sociological Analysis of Family Change in Postwar Japan, Tokyo.

Hazairin, Tanpa Tahun, Hukum Kewarisan Bilateral menurut Al-Qur'an dan Hadist, Jakarta: Tintamas.

Ibnu Rusyd, 1995, Bidayatul Mujtahid, Bairut: Darul Fikr.

Motonobu, Mukai, 2004, Modernization and Divorce in Japan, Marshal University.

Niswatul Hidayati, Rekonstruksi Hukum Waris Islam: Makna Kalalah David S. Power, Muslim Heritage, Vol 2: 1, Mei-Oktober 2017, 177-198.

NN, GambaranUmumMengenaiKeluargaIe, dikutipd ari http://repository.usu.ac.id/bitstream/123456789/37191/3/Chapter\%20II.p df, diakses 3 Februari 2014 NN, IsuJepangKontemporer, dikutipdarihttps://www.fitrianapd.lecture.ub.ac.id/files/2013/09/shoshika. pptx diakses 5 Februari 2014.

Satoshi Sakata, Historical Origin of the Japanese Ie System, dikutipdari http://www.yomiuri.co.jp/adv/chuo/dy/opinion/20130128.htm, diakses 3 Februari 2014.

Sayuti Thalib, 2016, Hukum Kewarisan Islam di Indonesia (Edisi Revisi), Jakarta: Sinar Grafika.

T.M Hasbi As-Shiddiqi, 2001, Fiqh Mawaris, Semarang: Pustaka Rizki Putra.

Tobing, Ekayani, 2006, Keluarga Tradisional Jepang Dalam Perspektif Sejarah dan Perubahan Sosial, Depok: ILUNI KWJ, 2006. 